\title{
Implementasi Rencana Induk Pengembangan Kawasan Sentul City Terhadap Limpasan Puncak dan Konstribusi Banjir
}

\author{
Implementation of the Master Plan in Sentul City on Peak Runoff \\ and Flood Contribution
}

\section{Asep Suheri ${ }^{1}$, Cecep Kusmana ${ }^{2}$, Moh. Yanuar J. Purwanto ${ }^{3}$}

Diterima: 3 Agustus 2019

Disetujui: 2 Juli 2020

\begin{abstract}
Abstrak: Tujuan penelitian ini adalah untuk membuat model limpasan puncak di kawasan perkotaan SC berdasarkan penggunaan lahan/penutupan lahan (Land Use/Land Cover, LU/LC) eksisting dan rencana induk pengembangan (master plan). Untuk menghitung limpasan puncak (Peak Run-off, PRO) dengan menggunakan metode rasional. Untuk mengetahui LU/LC saat ini (eksisting) melalui analisis citra SPOT-6 tahun 2017, dengan metode klasifikasi terbimbing (supervised classificatin) dengan estimasi parameter distribusi gamma dengan metode kemiripan maksimum (maximum likelihood) menggunakan software QGIS 2.8, SAGA GIS, dan Arc-GIS 10.4.1. Berdasarkan hasil analisis citra diperoleh dua belas jenis LU, yang dapat dikelompokkan kedalam tiga jenis LC, yaitu lahan terbangun 33\%, lahan bervegetasi (RTH) $65 \%$, dan lahan terbuka biru (RTB) $2 \%$. Hasil analisis menunjukkan bahwa implementasi master plan meningkatkan PRO. Dengan naiknya PRO akan berkonstribusi terhadap banjir di daerah hilir, konsekuensinya pihak pengembang harus bertanggungjawab untuk menurunkan PRO.
\end{abstract}

Kata Kunci: Limpasan puncak, penggunaan lahan, rencana induk pengembangan wilayah.

\begin{abstract}
The purpose of this study is to create a peak runoff model in urban SC areas based on existing land use/land cover (LU / LC) and a master plan. To calculate peak runoff (PRO) using the rational method. To find out the current LU / LC through existing SPOT-6 image analysis in 2017, using supervised classification method with an estimation of gamma distribution parameters with the maximum likelihood method using QGIS 2.8 software, SAGA GIS, and Arc -GIS 10.4.1. Based on the results of image analysis obtained twelve types of LU, which can be grouped into three types of LC, namely $33 \%$ of developed land, $65 \%$ of vegetated land (RTH), and $2 \%$ of blue open land (RTB). The analysis shows that the implementation of the master plan increases PRO. With the increase in PRO will contribute to flooding in the downstream areas, consequently the developer must be responsible for reducing the PRO.
\end{abstract}

Keywords: Peak runoff, land use, master plan

\footnotetext{
1 Sekolah Ilmu dan Teknologi Hayati, Institut Teknologi Bandung, Bandung

2 Departemen Silvikultur, Fakultas Kehutanan, IPB University, Bogor

3 Departemen Teknik Sipil dan Lingkungan, Fakultas Teknologi Pertanian, IPB University, Bogor
} 


\section{PENDAHULUAN}

Kawasan Sentul City (SC) merupakan kota mandiri di Kabupaten Bogor yang dikembangkan oleh PT Sentul City Tbk. SC mengembangkan kawasannya dengan prinsip green development melalui respon terhadap parameter city. Konsep eco-city diterapkan pada lanskap maupun bangunan. Kawasan ini dibangun sebagai kawasan perumahan, perdagangan, perkantoran, industri, pariwisata, serta fasilitas khusus (komersial). SC merupakan kawasan yang miskin air, karena kondisi geohidrologis daerah tersebut yang tidak memungkinkan untuk menyimpan air karena tekstur tanahnya didominiasi oleh tekstur liat. Potensi ketersediaan air di SC akan tergantung pada kondisi biofisik meliputi: penggunaan lahan/penutupan lahan (Land Use/Land Cover, LU/LC), topografi, hidrologi, klimatologi, mahluk hidup, jenis tanah, vegetasi, satwa, dan lain-lain.

Konsep pengembangan kawasan SC seperti dituangkan dalam rencana induk pengembangan (Master plan) yang membagi kawasan SC menjadi dua area, yaitu area bangunan dan tutupan (termasuk area konservasi). Area konservasi yang direncanakan berupa hutan taman, taman bermain, dan danau buatan (Seyhan, 1990). SC berkomitmen menjaga keseimbangan antara ruang terbangun dengan ruang terbuka.

Dengan telah disyahkan Rencana Induk Pengembangan (Master plan) SC oleh pihak Bappeda Kabupaten Bogor pada tahun 2011, dipandang perlu untuk melakukan penelitian dampak implementasi Master plan (2011) terhadap besarnya limpasan puncak, dan bagaimana limpasan tersebut berkontribusi terhadap banjir di daerah hilir. Adapun tujuan penelitian adalah untuk membuat model limpasan puncak di kawasan perkotaan SC berdasarkan LU eksisting dan masterplan.

Aliran permukaan (limpasan) merupakan bagian dari curah hujan yang mengalir di atas permukaan tanah dan mengangkut partikel-partikel tanah menuju sungai, danau, dan lautan (Asdak, 2010). Sifat limpasan seperti jumlah atau volume, laju atau kecepatan, dan gejolak limpasan menentukan kemampuannya dalam menimbulkan erosi. Besaran limpasan dinyatakan dalam satuan mm (Haridjaja dkk, 1991). Limpasan terjadi karena intensitas hujan yang jatuh di suatu daerah melebihi kapasitas infiltrasi, setelah laju infiltrasi terpenuhi air akan mengisi cekungan-cekungan pada permukaan tanah. Setelah cekungan-cekungan tersebut penuh, selanjutnya air akan mengalir (melimpas) di atas permukaan tanah (surface run-off). Jika aliran air terjadi di bawah permukaan tanah disebut sebagai aliran di bawah permukaan dan jika yang terjadi aliran yang berada di lapisan equifer (air tanah), maka disebut aliran air tanah.

Faktor-faktor yang mempengaruhi limpasan dibagi menjadi dua kelompok, yaitu elemen meteorologi dan elemen sifat fisik daerah pengaliran (Theodore et al, 2011). Elemen meteorologi meliputi jenis presipitasi, intensitas hujan, durasi hujan, dan distribusi hujan dalam daerah pengaliran, sedangkan elemen sifat fisik daerah pengaliran meliputi tata guna lahan (LU), jenis tanah, dan kondisi topografi daerah pengaliran (catchment).

Elemen sifat fisik dapat dikategorikan sebagai aspek statis sedangkan elemen meteorologi merupakan aspek dinamis yang dapat berubah terhadap waktu. Ada banyak metode yang dapat dipakai untuk menganalisa dan memprediksi besaran limpasan, beberapa diantaranya adalah metode rasional, Soil Conservation Service (SCS), dan modifikasi rasional (Needhidasan \& Manoj, 2013).

Metode Rasional awalnya banyak digunakan untuk memperkirakan debit puncak yang ditimbulkan oleh hujan deras pada daerah tangkapan (DAS) kecil. Suatu DAS disebut DAS kecil apabila distribusi hujan dapat dianggap seragam dalam suatu ruang dan waktu, dan biasanya durasi hujan melebihi waktu konsentrasi. Metode Rasional dapat menggambarkan hubungan antara debit limpasan dengan besar curah hujan, secara praktis berlaku untuk luas DAS kurang dari 300 hektar (Goldman, Jackson \& Bursztynsky, 1986). 
Koefisien limpasan $(C)$ didefinisikan sebagai nisbah antara laju puncak aliran permukaan terhadap intensitas hujan yang dipengaruhi oleh laju infiltrasi tanah, tanaman penutup tanah, dan intensitas hujan. Faktor utama yang mempengaruhi nilai $\mathrm{C}$ adalah laju infiltrasi tanah, tanaman penutup tanah dan intensitas hujan (Arsyad, 2010). C merupakan bilangan yang menunjukkan perbandingan antara besarnya air larian terhadap besarnya curah hujan (dalam suatu DAS). C menunjukkan pengaruh LU, tanah, lereng, dan potensial aliran permukaan. LU di wilayah urban yang menyebabkan pemadatan tanah dan pembuatan lapisan kedap di permukaan tanah akan menghasilkan $\mathrm{C}$ yang lebih besar. Nilai C sangat tergantung pada intensitas hujan (I). Jika I rendah, maka C rendah. Sebaliknya, jika I tinggi, maka $\mathrm{C}$ tinggi. Selain itu, nilai $\mathrm{C}$ sangat dipengaruhi laju infiltrasi dan LC.

Menurut Asdak (2010), C adalah bilangan yang menunjukkan perbandingan antara aliran permukaan terhadap besarnya curah hujan. Secara matematis, nilai C dirumuskan pada persamaan (1) yang mengacu pada metode Cook. Angka $\mathrm{C}$ merupakan indikator yang menunjukkan kondisi fisik suatu DAS. Angka C berkisar $0-1$. Semakin besar nilai $\mathrm{C}$ atau mendekati 1 maka semakin banyak curah hujan yang menjadi limpasan atau jumlah air yang terinfiltrasi semakin sedikit. Nilai $\mathrm{C}$ diperoleh dengan menggunakan parameter lereng, infiltrasi, presentase vegetasi, dan skor kerapatan aliran (Gunawan dkk, 2012).

Koefisien Limpasan $(\mathrm{C})=$ aliran permukaan $(\mathrm{mm}) /$ curah hujan $(\mathrm{mm})$

LU dan LC sering digunakan secara bersama-sama, namun kedua terminologi tersebut berbeda. LC berkaitan dengan jenis kenampakan yang ada di permukaan bumi, sedangkan LU berkaitan dengan kegiatan manusia pada obyek tersebut (Lillesand \& Kiefer, 1994). LC adalah perwujudan secara fisik (visual) dari vegetasi, benda alam, dan unsur-unsur budaya yang ada di permukaan bumi tanpa memperhatikan kegiatan manusia terhadap obyek tersebut (Townshend \& Justice, 1981). Permukaan bumi sebagian terdiri dari kenampakan alamiah (LC) seperti vegetasi, salju, dan lain sebagainya, serta sebagian lagi berupa kenampakan hasil aktivitas manusia berupa LU (Barret \& Curtis, 1982).

Dari beberapa tinjauan pustaka tersebut di atas tersirat bahwa LU adalah klasifikasi lahan berdasarkan aktivitas manusia, sedangkan LC adalah karakteristik alamiah dari lahan tersebut. LC bisa dianggap sebagai kondisi saat ini, sedangkan LU berkaitan dengan status lahan. Penekanan di sini adalah bahwa analisis lahan seperti hidrologi, lanskap, dan lain-lain harus menggunakan LC. Namun, LC itu sendiri akan dipengaruhi oleh status penggunaan. Contohnya, suatu lahan berhutan jika berada dalam LU pertambangan akan tidak tepat dianalisis menggunakan LC jika rentang studi cukup lebar karena aktivitas pertambangan akan mengubah LC berhutan tersebut dalam kisaran waktu analisis.

Perubahan tata guna lahan merupakan penyebab utama banjir bila di bandingkan dengan faktor lain. Perlu pula diketahui bahwa perubahan tata guna lahan memberikan kontribusi dominan kepada limpasan (runoff). Hujan yang jatuh ke tanah, airnya akan menjadi limpasan di atas tanah dan sebagian meresap ke dalam tanah tergantung kondisi tanahnya (Kodoatie \& Sjarief, 2008). Faktor LC vegetasi cukup signifikan dalam pengurangan atau peningkatan limpasan. Hutan yang lebat mempunyai tingkat penutup lahan yang tinggi, sehingga apabila hujan turun ke wilayah hujan tersebut, faktor LC ini memperlambat kecepatan aliran permukaan, bahkan bisa terjadi kecepatannya mendekati nol. Ketika suatu kawasan hutan menjadi pemukiman, maka LC kawasan ini akan berubah menjadi LC yang tidak mempunyai resistensi untuk menahan aliran. Yang terjadi ketika hujan turun, kecepatan air akan meningkat sangat tajam di atas lahan ini. Namun resapan air yang masuk ke dalam tanah relatif tetap kecuali lahannya berubah. Kuantitas totalnya berubah karena tergantung dari luasan penutup lahan (Kodoatie \& Sjarief, 2008). 
Penginderaan jauh (atau disingkat inderaja) adalah pengukuran atau akuisisi data dari sebuah objek atau fenomena oleh sebuah alat yang tidak secara fisik melakukan kontak dengan objek tersebut atau pengukuran atau akuisisi data dari sebuah objek atau fenomena oleh sebuah alat dari jarak jauh, (misalnya dari pesawat, pesawat luar angkasa, satelit, kapal atau alat lain). Contoh dari penginderaan jauh antara lain satelit pengamatan bumi, satelit cuaca, memonitor janin dengan ultrasonik dan wahana luar angkasa yang memantau planet dari orbit. Inderaja berasal dari bahasa Inggris remote sensing, bahasa Perancis télédétection, bahasa Jerman fernerkundung, bahasa Portugis sensoriamento remota, bahasa Spanyol percepcion remote dan bahasa Rusia distangtionaya. Di masa modern, istilah penginderaan jauh mengacu kepada teknik yang melibatkan instrumen di pesawat atau pesawat luar angkasa dan dibedakan dengan penginderaan lainnya seperti penginderaan medis atau fotogrametri. Walaupun semua hal yang berhubungan dengan astronomi sebenarnya adalah penerapan dari penginderaan jauh (faktanya merupakan penginderaan jauh yang intensif), istilah "penginderaan jauh" umumnya lebih kepada yang berhubungan dengan teresterial dan pengamatan cuaca (Lillesand \& Kiefer, 1994).

Interpretasi citra merupakan upaya untuk menafsirkan citra sehingga mendapatkan informasi yang akurat dan sesuai dengan obyek yang terekam. Unsur-unsur yang digunakan sebagai dasar analisis meliputi: ukuran, rona (tone), warna, tekstur, pola dan resolusi (Lillesand and Kiefer, 1994). Dalam penelitian ini interpretasi citra menghasilkan tujuh penggunaan lahan yakni: hutan, kebun, lahan terbangun, sawah, tegalan, tubuh air dan lainlain.

Hutan pada citra SPOT/Landsat dicirikan dengan warna hijau tua dengan tekstur halus dan berlereng curam. Interpretasi penggunaan lahan hutan pada citra SPOT/Landsat relatif mudah karena warna dan tekstur berbeda dibandingkan dengan penggunaan lahan lainnya serta lokasi hutan umumnya berada pada wilayah-wilayah dengan lereng yang terjal. Kebun merupakan kelompok vegetasi campuran antara tanaman tahunan (buah-buahan) dengan tanaman semusim. Kenampakan kebun pada citra ditandai dengan warna hijau terang dengan tekstur kasar dan bergerombol. Sementara tegalan merupakan kelompok vegetasi campuran dimana lebih banyak tanaman rendah seperti palawija dan sayuran. Kenampakan tegalan pada citra kadang-kadang sulit dibedakan dengan kebun, namun tegalan memiliki ciri khas warna hijau terang kecoklatan dengan tekstur kasar dan lokasinya biasanya dekat dengan permukiman. Sawah pada citra SPOT/Landsat memiliki beberapa kenampakan tergantung pada fase penanamannya. Pada fase vegetatif dan tergenang air, kenampakan sawah pada citra akan berwarna hijau kebiru-biruan, jika fase reproduktif dan pematangan warna sawah hijau kekuningan. Sementara pada saat diberakan warna sawah akan menjadi kecoklatan. Dari sekian macam warna sawah pada kenampakan citra tersebut, unsur yang memudahkan klasifikasi adalah tekstur halus dan pola kotak-kotak yang mencirikan petakan lahan. Lahan terbangun (built-up area) meliputi permukiman baik padat maupun jarang, kawasan industri dan perkantoran serta sarana infrastruktur sosial ekonomi lainnya. Kenampakan lahan terbangun pada citra SPOT/Landsat dicirikan dengan warna merah muda hingga keunguunguan dengan tekstur kasar dan bergerombol dan polanya mengikuti jaringan jalan. Tubuh air meliputi sungai dan danau/situ. Kenampakannya pada citra dicirikan dengan warna biru tua dan keberadaannya menyebar di seluruh wilayah dengan luasan yang sangat kecil. Dari keenam kelas penggunaan lahan hasil interpretasi, ada sebagian kecil penggunaan lahan yang tidak dapat dimasukkan ke dalam klasifikasi tersebut, misalnya tanah terbuka, semak belukar, empang. Oleh karena itu dalam penelitian ini ketiga penggunaan lahan tersebut dikelompokkan ke dalam kelas lain-lain.

Informasi Geospasial (disingkat IG) adalah data geospasial (DG) yang sudah diolah sehingga dapat digunakan sebagai alat bantu dalam perumusan kebijakan, pengambilan keputusan, dan/atau pelaksanaan kegiatan yang berhubungan dengan ruang kebumian. 
Informasi Geospasial Dasar (disingkat IGD) adalah Informasi Geospasial yang berisi tentang objek yang dapat dilihat secara langsung atau diukur dari kenampakan fisik di muka bumi dan yang tidak berubah dalam waktu yang relatip lama. Informasi Geospasial Tematik yang selanjutnya disingkat IGT adalah IG yang menggambarkan satu atau lebih tema tertentu yang dibuat mengacu pada IGD (UU RI No. 4 Tahun 2011).

Sistem Informasi Geospasial (SIG) atau Geospatial Information System (GIS) adalah suatu sistem informasi yang dirancang untuk bekerja dengan data yang bereferensi spasial atau berkoordinat geografi atau dengan kata lain suatu SIG adalah suatu sistem basis data dengan kemampuan khusus untuk menangani data yang bereferensi keruangan (spasial) bersamaan dengan seperangkat operasi kerja (Barus \& Wiradisastra, 2000). Sedangkan Sistem Informasi Geografis adalah suatu sistem Informasi yang dapat memadukan antara data grafis (spasial) dengan data teks (atribut) objek yang dihubungkan secara geogrfis di bumi (georeference). Disamping itu, SIG juga dapat menggabungkan data, mengatur data dan melakukan analisis data yang akhirnya akan menghasilkan keluaran yang dapat dijadikan acuan dalam pengambilan keputusan pada masalah yang berhubungan dengan geografi. SIG dibagi menjadi dua kelompok yaitu sistem manual (analog), dan sistem otomatis (yang berbasis digital komputer). Perbedaan yang paling mendasar terletak pada cara pengelolaannya. Sistem Informasi manual biasanya menggabungkan beberapa data seperti peta, lembar transparansi untuk tumpang susun (overlay), foto udara, laporan statistik dan laporan survey lapangan. Kesemua data tersebut dikompilasi dan dianalisis secara manual dengan alat tanpa komputer. Sedangkan SIG otomatis telah menggunakan komputer sebagai sistem pengolah data melalui proses digitasi. Sumber data digital dapat berupa citra satelit atau foto udara digital serta foto udara yang terdigitasi. Data lain dapat berupa peta dasar terdigitasi (Nurshanti. 1995).

Pengertian GIS/SIG saat ini lebih sering diterapkan bagi teknologi informasi spasial atau geografi yang berorientasi pada penggunaan teknologi komputer. Dalam hubungannya dengan teknologi komputer, SIG sebagai sistem berbasis komputer yang memiliki kemampuan dalam menangani data bereferensi geografi yaitu pemasukan data, manajemen data (penyimpanan dan pemanggilan kembali), memanipulasi dan analisis data, serta keluaran sebagai hasil akhir (output) (Aronoff, 1989). SIG sebagai sistem berbasis komputer yang digunakan untuk memasukkan, menyimpan, mengelola, menganalisis dan mengaktifkan kembali data yang mempunyai referensi keruangan untuk berbagai tujuan yang berkaitan dengan pemetaan dan perencanaan (Burrough, 1987). Komponen utama SIG dapat dibagi kedalam 4 komponen utama yaitu: perangkat keras (digitizer, scanner, Central Procesing Unit (CPU), hard-disk, dan lain-lain), perangkat lunak (ArcView, Idrisi, ARC/INFO, ILWIS, MapInfo, dan lain-lain), organisasi (manajemen) dan pemakai (user). Kombinasi yang benar antara keempat komponen utama ini akan menentukan kesuksesan suatu proyek pengembangan SIG.

Tujuan pokok dari pemanfaatan SIG adalah untuk mempermudah mendapatkan informasi yang telah diolah dan tersimpan sebagai atribut suatu lokasi atau obyek. Ciri utama data yang bisa dimanfaatkan dalam SIOG adalah data yang telah terikat dengan lokasi dan merupakan data dasar yang belum dispesifikasi (Dulbahri, 1993). Data-data yang diolah dalam SIG pada dasarnya terdiri dari data spasial (spatial) dan data atribut (attribute) dalam bentuk digital, dengan demikian analisis yang dapat digunakan adalah analisis spasial dan analisis atribut. Data spasial merupakan data yang berkaitan dengan lokasi keruangan yang umumnya berbentuk peta. Sedangkan data atribut merupakan data tabel yang berfungsi menjelaskan keberadaan berbagai objek sebagai data spasial.

Penyajian data spasial mempunyai tiga cara dasar yaitu dalam bentuk titik, bentuk garis dan bentuk area (polygon). Titik merupakan kenampakan tunggal dari sepasang koordinat $\mathrm{x}, \mathrm{y}$ yang menunjukkan lokasi suatu obyek berupa ketinggian, lokasi kota, lokasi pengambilan 
sample dan lain-lain. Garis merupakan sekumpulan titik-titik yang membentuk suatu kenampakan memanjang seperti sungai, jalan, kontus dan lain-lain. Sedangkan area adalah kenampakan yang dibatasi oleh suatu garis yang membentuk suatu ruang homogen, misalnya: batas daerah, batas LU, pulau dan lain sebagainya.

Struktur data spasial dibagi dua yaitu model data raster dan model data vektor. Data raster adalah data yang disimpan dalam bentuk kotak segi empat (grid)/sel sehingga terbentuk suatu ruang yang teratur. Data vektor adalah data yang direkam dalam bentuk koordinat titik yang menampilkan, menempatkan dan menyimpan data spasial dengan menggunakan titik (point), garis (line) atau area (polygon)( Barus \& Wiradisastra, 2000).

Sistem informasi geografi menyajikan informasi keruangan beserta atributnya yang terdiri dari beberapa komponen utama (Dulbahri. 1993) yaitu:

1. Masukan data merupakan proses pemasukan data pada komputer dari peta (peta topografi dan peta tematik), data statistik, data hasil analisis penginderaan jauh data hasil pengolahan citra digital penginderaan jauh, dan lain-lain. Data-data spasial dan atribut baik dalam bentuk analog maupun data digital tersebut dikonversikan kedalam format yang diminta oleh perangkat lunak sehingga terbentuk basisdata (database). Basisdata adalah pengorganisasian data yang tidak berlebihan dalam komputer sehingga dapat dilakukan pengembangan, pembaharuan, pemanggilan, dan dapat digunakan secara bersama oleh pengguna.

2. Penyimpanan data dan pemanggilan kembali (data storage dan retrieval) ialah penyimpanan data pada komputer dan pemanggilan kembali dengan cepat (penampilan pada layar monitor dan dapat ditampilkan/cetak pada kertas).

3. Manipulasi data dan analisis ialah kegiatan yang dapat dilakukan berbagai macam perintah misalnya overlay antara dua tema peta, membuat buffer zone jarak tertentu dari suatu area atau titik dan sebagainya. Manipulasi dan analisis data merupakan ciri utama dari SIG. Kemampuan SIG dalam melakukan analisis gabungan dari data spasial dan data atribut akan menghasilkan informasi yang berguna untuk berbagai aplikasi

4. Pelaporan data ialah dapat menyajikan data dasar, data hasil pengolahan data dari model menjadi bentuk peta atau data tabular. Bentuk produk suatu SIG dapat bervariasi baik dalam hal kualitas, keakuratan dan kemudahan pemakainya (Barus \& Wiradisastra, 2000). Hasil ini dapat dibuat dalam bentuk peta-peta, tabel angka-angka: teks di atas kertas atau media lain (hard copy), atau dalam cetak lunak (seperti file elektronik).

\section{METODE}

\section{Lokasi dan Waktu Penelitian}

Tempat penelitian berada di Sentul City yang merupakan sebuah kawasan kota pegunungan dengan luas efektif sebesar 2.905,33 ha dari luas 3.001,4 ha. Lokasi ini terletak pada koordnat $6^{\circ} 34^{\prime} 4,68^{\prime \prime}-6^{\circ} 34^{\prime} 55,19$ " LS dan $106^{\circ} 51^{\prime} 4,10$ " - 106 $54^{\circ} 34,20$ " BT, di sebelah timur kota Bogor yang dikembangkan oleh PT Sentul City Tbk. Waktu pelaksanaan penelitian dimulai pada bulan Juli 2017 sampai dengan Mei 2019.

\section{Metode Pengumpulan Data}

Data yang digunakan dalam penelitian ini terdiri dari data primer dan data sekunder. Data primer diperoleh melalui observasi lapangan dan wawancara mendalam (In depth Interview) dengan pakar/responden. Data sekunder diperoleh dari instansi-instansi terkait dapat berupa data softcopy dan hardcopy dokumentasi laporan kegiatan yang telah dilakukan. 


\section{Jenis dan sumber data}

Bahan yang digunakan dalam penelitian ini adalah citra SPOT-6 tahun 2017; peta RBI skala 1 : 25.000; DEM-SRTM; data curah hujan 2009 - 2018; jumlah penduduk; debit harian dan bulanan sungai Cikeas dan Citeureup; DAM; hasil observasi lapangan dan hasil wawancara (quesioner) dengan 5 ahli/ expert. Alat bantu yang digunakan adalah software ArcGIS 10.4.1, QGIS 3.8, Global Mapper 17.0, Super Decision 2.8.0, Stella 9.0.1, dan Microsoft office 2016.

Sumber datanya adalah: Lapan; BIG; USGS; BPS, Bappeda, survai lapangan, FGD stakeholder, peraturan/kebijakan, RTRW, BBWS Citarum, BBWS Ciliwung-Cisadane, BPDAS Citarum-Ciliwung, Bappeda Provinsi/ Kabupaten, dan Dinas PSDA

Pakar dipilih dari orang yang mengetahui dan menguasai informasi terkait pemanfaatan badan air dan bantaran banjir sebagai sumber air baku. Pakar tersebut berasal dari: Instansi pusat (Kementerian PUPR), daerah (Dinas PSDA), dan PDAM Kabupaten Bogor

\section{Metode Analisis Data}

\section{Menentukan Jenis Penggunaan Lahan (LU)}

Informasi LC dapat diperoleh dari citra penginderaan jauh (remote sensing), foto udara, foto satelit serta teknologi lainnya yang dapat digunakan dalam mengidentifikasi LC. Sedangkan untuk informasi LU dapat diperoleh dengan pengecekan langsung/survey lapang. Dari informasi LC yang ada dapat digunakan sebagai informasi awal dalam mendapatkan informasi LU.

Untuk menentukan jenis LC eksisting di wilayah kajian. Tahap pertama dilakukan proses georeference terhadap citra SPOT-6 untuk mendapatkan posisi geografi secara tepat. Sistem referensi koordinat yang digunakan adalah Universal Transver Mercator (UTM). Sesuai pembagian zona UTM di Indonesia, kawasan SC terletak pada UTM Zona 48S. Dengan demikian, peta diproyeksikan pada WGS84/UTM Zona 48S/EPSG:32748. Tahap kedua, dilakukan supervised classification atau klasifikasi terbimbing terhadap peta citra. Metode yang digunakan adalah maximum likelihood classification. Akan dihasilkan peta LC wilayah kajian. Kemudian dilakukan ground check untuk mengetahui LC kawasan perkotaan SC secara langsung. Hasil analisis LC dinilai akurasinya dengan menggunakan overall accuracy dan kappa accuracy.

\section{Menentukan C}

Menentukan koefisien limpasan (C) dihitung dengan menggunakan persamaan sebagai berikut (Kasiro, 1994):

$$
\begin{aligned}
& \mathrm{C}=(\mathrm{d} i \times 86.400 \times \mathrm{Q}) /(\mathrm{P} \times \mathrm{A}) \\
& \text { dengan: } \\
& \mathrm{C}=\text { Air larian }(\mathrm{mm}) / \text { Curah hujan }(\mathrm{mm}) \\
& \mathrm{d} i=\text { Jumlah hari dalam bulan ke }-\mathrm{i} \\
& \mathrm{Q}=\text { Debit rata-rata bulanan }\left(\mathrm{m}^{3} / \text { detik) dan } 86.400=\text { jumlah detik dalam } 24\right. \text { jam }
\end{aligned}
$$

(60 menit, 60 detik, 24 jam).

$\mathrm{P}=$ Curah hujan rata-rata setahun ( $\mathrm{mm} /$ tahun)

$\mathrm{A}=$ Luas DAS $\left(\mathrm{km}^{2}\right)$

Nilai koefisien limpasan SC $\left(C_{S C}\right)$ berdasarkan peta penggunaan lahan tahun 2017 dapat dihitung dengan persamaan sebagai berikut:

$$
C_{-} S C=\frac{\sum_{i=1}^{n} C_{i} A_{i}}{\sum_{i=1}^{n} A_{i}}
$$

dimana: 
$C_{S C}=$ koefisien limpasan wilayah SC

$\mathrm{A}_{\mathrm{i}} \quad=\quad$ luas lahan dengan tutupan tanah ke-i (ha)

$\mathrm{C}_{\mathrm{i}} \quad=\quad$ koefisien limpasan jenis penutup tanah ke-i

$\mathrm{n}=\quad$ jumlah jenis penutup tanah

Nilai koefisien limpasan (C) pada berbagai penggunaan lahan (LU) disajikan pada Tabel 1.

Table 1. Klasifikasi LU dan C

\begin{tabular}{lcl}
\hline \multicolumn{2}{l}{ Koefisien limpasan ( c ) } & Tipe penggunaan lahan \\
\hline c1 & 0,95 & Jalan aspal \\
c2 & 0,90 & Industri, terminal utama, pergudangan umum, perusahaan \\
c3 & 0,80 & Perdagangan \\
c4 & 0,65 & Perumahan \\
c5 & 0,50 & Fasilitas dan layanan pendidikan \\
c6 & 0,25 & Ruang terbuka, sabuk hijau, pemakaman \\
\hline
\end{tabular}

Source: US Forest Service (1980) in Asdak (1995)

\section{Metode Rasional}

Untuk menentukan puncak limpasan di kawasan SC (Qp_SC) pada penelitian ini menggunakan metode rasional, yang dihitung dengan persamaan sebagai berikut (Arsyad, 2010; Asdak, 2010):

Qp_SC $=0,278 \times C_{S C} \times \mathrm{I} \times \mathrm{A}$

dimana:

Qp_SC $=$ Puncak limpasan kawasan SC (m³/detik)

$C_{S C} \quad=$ Koefisen limpasan untuk berbagai LU di kawasan SC

I $\quad=$ Intensitas hujan $(\mathrm{mm} / \mathrm{jam})$

A = Luas wilayah kajian $\left(\mathrm{km}^{2}\right)$

Metode rasional biasa dapat digunakan untuk wilayah studi dengan cakupan kecil, sedangkan untuk cakupan wilayah besar perlu digunakan metode modifikasi rasional (Townshend and Justice, 1981). Arti rumus di atas yakni jika terjadi curah hujan selama 1 jam dengan intensitas $1 \mathrm{~mm} /$ jam dalam daerah seluas $1 \mathrm{~km}^{2}$, maka debit banjir sebesar 0,2778 $\mathrm{m}^{3} /$ detik dan melimpas selama 1 jam (Sosrodarsono \& Takeda, 2003).

\section{HASIL DAN PEMBAHASAN}

\section{LU Eksisting}

Berdasarkan klasifikasi penutupana lahan pada citra SPOT 2017 dengan dibantu oleh peta penggunaan lahan tahun 2015, diperoleh penggunaan lahan di SC sebagaimana disajikan pada Tabel 2. Hasil dari analisis data menunjukkan bahwa kondisi eksisting penggunaan lahan di lokasi studi terdiri dari 12 kelas tutupan lahan utama, dan sebagian besar lahan berupa tegalan sebesar $41.77 \%$ diikuti oleh pemukiman perkotaan $24.48 \%$ dan kebun campuran $10.23 \%$, perairan darat $0.22 \%$ dan lahan terbuka $0.33 \%$ adalah area terkecil di wilayah penelitian. LU eksisting (pada tahun 2017) di kawasan SC disajikan pada Gambar 1. 


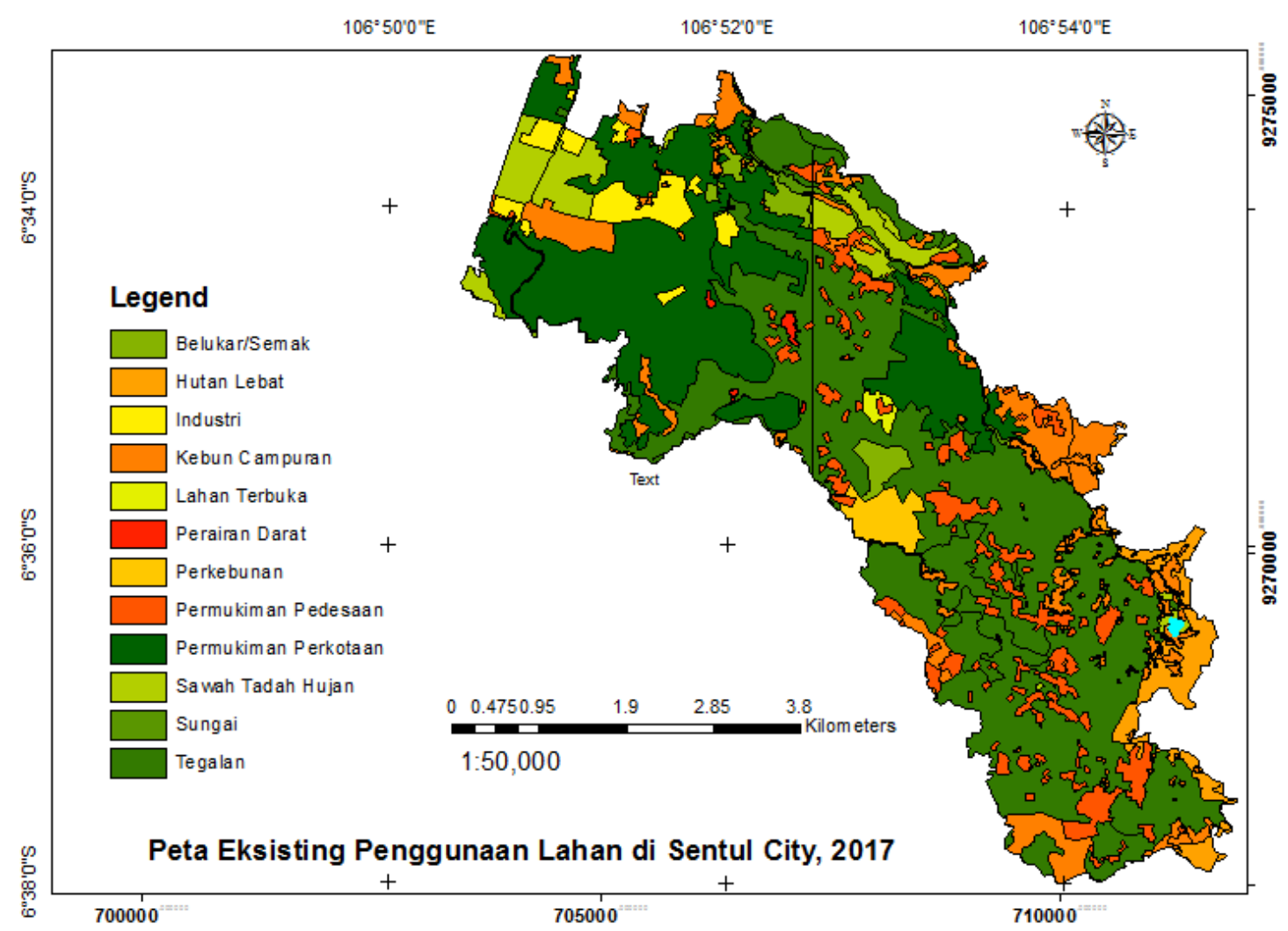

Gambar 1. Eksisting penggunaan lahan SC

Tabel 2. Eksisting Penggunaan Lahan dan Koefisien Limpasan di SC

\begin{tabular}{|c|c|c|c|c|c|}
\hline \multirow{2}{*}{ No } & \multirow{2}{*}{ Jenis Penggunaan Lahan } & \multicolumn{2}{|c|}{ Luas } & \multirow{2}{*}{ Nilai C } & \multirow{2}{*}{ Nilai Cpl } \\
\hline & & ha & Prosen $(\%)$ & & \\
\hline 1 & Belukar/Semak & 49.02 & 1.69 & 0.25 & 12.26 \\
\hline 2 & Hutan Lebat & 101.69 & 3.50 & 0.05 & 5.08 \\
\hline 3 & Industri & 78.83 & 2.71 & 0.90 & 70.95 \\
\hline 4 & Kebun Campuran & 297.16 & 10.23 & 0.25 & 74.29 \\
\hline 5 & Lahan Terbuka & 9.56 & 0.33 & 0.20 & 1.91 \\
\hline 6 & Perairan Darat & 6.36 & 0.22 & 0.03 & 0.19 \\
\hline 7 & Perkebunan & 42.68 & 1.47 & 0.25 & 10.67 \\
\hline 8 & Permukiman Pedesaan & 225.07 & 7.75 & 0.50 & 112.54 \\
\hline 9 & Permukiman Perkotaan & 705.47 & 24.28 & 0.75 & 529.10 \\
\hline 10 & Sawah Tadah Hujan & 146.12 & 5.03 & 0.20 & 29.22 \\
\hline 11 & Sungai & 29.85 & 1.03 & 0.05 & 1.49 \\
\hline \multirow[t]{3}{*}{12} & Tegalan & $1,213.52$ & 41.77 & 0.25 & 303.38 \\
\hline & Jumlah & $2,905.33$ & 100.00 & - & $1,151.08$ \\
\hline & $C_{S C}$ & - & - & - & 0.40 \\
\hline
\end{tabular}

Sumber: Hasil analisis data, 2019

\section{Rencana Induk Pengembangan (Master plan)}

Pembangunan berbagai macam sarana dan prasarana serta fasilitas pada kawasan permukiman SC bertujuan untuk memenuhi berbagai macam kebutuhan penghuni serta bersifat memberikan pelayanan pusat kawasan dan pelayanan pusat lingkungan. Peruntukan lahan yang efektif yaitu seluas 2.465 ha. Luas lahan efektif dimanfaatkan untuk perumahan dan fasilitasnya, luas lahan yang tidak efektif ini keadaan kemiringan lerengnya lebih dari 
$40 \%$. Semua terlihat pada rencana peruntukan lahan efektif dan rencana peruntukan lahan terbangun dengan proporsi terhadap luas area 2.465 ha. Wilayah terbangun dengan proporsi terhadap luas area 2.465 ha yaitu 29,95\%.

Tabel 4. Rencana induk penggunaan lahan (Master plan, 2011)

\begin{tabular}{|c|c|c|c|c|c|}
\hline \multirow[b]{2}{*}{ No. } & \multirow{2}{*}{$\begin{array}{l}\text { Jenis Penggunaan- } \\
\text { Lahan }\end{array}$} & \multicolumn{2}{|r|}{ Luas } & \multirow[t]{2}{*}{ Nilai C } & \multirow[t]{2}{*}{ Nilai Cpl } \\
\hline & & ha & Prosen (\%) & & \\
\hline 1 & Enclave & 63,20 & 2,18 & 0,75 & 47,40 \\
\hline 2 & Komersial & 459,35 & 15,81 & 0,85 & 390,45 \\
\hline 3 & Pedesaan & 277,37 & 9,55 & 0,60 & 166,42 \\
\hline 4 & Pemukiman & 23,18 & 0,80 & 0,75 & 17,39 \\
\hline 5 & Perumahan & $1.638,19$ & 56,38 & 0,60 & 982,91 \\
\hline 6 & Prasarana & 61,40 & 2,12 & 0,90 & 55,26 \\
\hline 7 & Sarana efektif & 6,56 & 0,23 & 0,95 & 6,23 \\
\hline 8 & Sarana konservasi & 376,08 & 12,94 & 0,25 & 94,02 \\
\hline Total & & $2.905,33$ & 100,00 & - & $1.760,08$ \\
\hline CSC & & & & & 0,61 \\
\hline
\end{tabular}

Proporsi ruang terbuka hijau pada wilayah kota paling sedikit $30 \%$ dari wilayah kota, maka permukiman SC sudah memenuhi persyaratan tentang ruang terbuka hijau (Burrough, 1987). Tata guna lahan di dalam cluster BGH sendiri hanya terbagi menjadi wilayah permukiman, fasilitas, RTH, dan kavling kosong. Rencana induk LU disajikan pada Gambar 2.

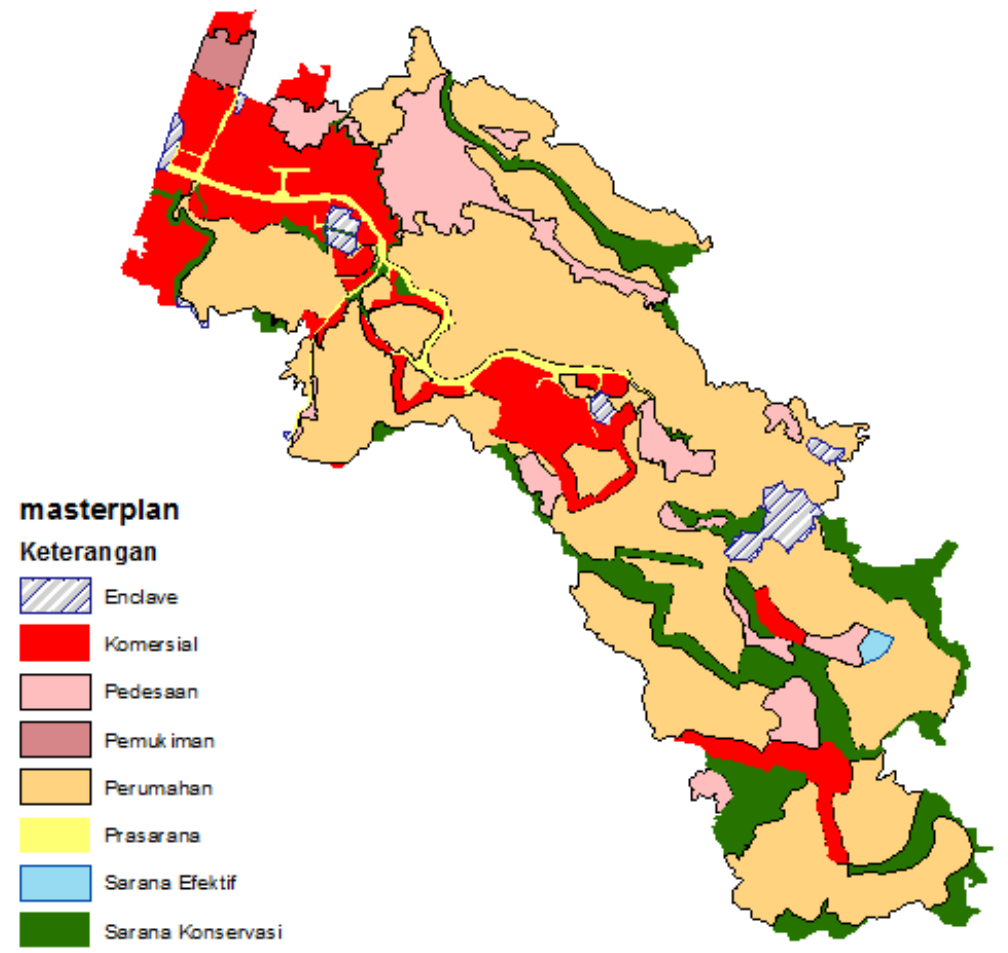

Gambar 2. Rencana Induk Penggunaan Lahan. 
Rencana induk LU di Kawasan SC tertuang pada rencana induk pengembangan atau masterplan SC. Area yang direncanakan sebagai lahan terbangun adalah sebesar 2.431,31 ha atau $83.68 \%$ Tabel 5.

Tabel 5. Rencana pemanfaatan lahan pada Master plan SC

\begin{tabular}{|c|c|c|c|}
\hline \multicolumn{2}{|c|}{ Rencana penggunaan lahan } & \multicolumn{2}{|r|}{ Luas } \\
\hline & & ha & Prosen (\%) \\
\hline \multirow{5}{*}{ Lahan terbangun } & Prasarana & 55,40 & 1,91 \\
\hline & Jaringan jalan & 90,22 & 3,11 \\
\hline & Perumahan dan fasilitas & $1.624,55$ & 55,92 \\
\hline & Pemukiman & 276,02 & 9,50 \\
\hline & Komersial & 385,12 & 13,26 \\
\hline Jumlah & & $2.431,31$ & 83,68 \\
\hline \multirow{3}{*}{ Ruang Terbuka Hijau } & Sempadan sungai & 344,86 & 11,87 \\
\hline & Lapangan golf & 85,78 & 2,95 \\
\hline & Taman rekreasi dan olah raga & 14,30 & 0,49 \\
\hline Jumlah & & 444,94 & 15,31 \\
\hline Ruang Terbuka Biru & Sungai dan danau & 29,08 & 1,00 \\
\hline Total & & $2.905,33$ & 100,00 \\
\hline
\end{tabular}

Sumber: Sentul City (2011).

\section{Curah Hujan}

Curah hujan dihitung dengan satuan $\mathrm{mm}$ (milimeter), yaitu tinggi air yang tertampung pada area seluas $1 \mathrm{~m} \mathrm{x} 1 \mathrm{~m}$ alias 1 meter persegi $\left(\mathrm{m}^{2}\right)$. Jadi curah hujan $1 \mathrm{~mm}$ adalah jumlah air yang turun dari langit sebanyak $1 \mathrm{~mm} \times 1 \mathrm{~m} \times 1 \mathrm{~m}$ atau $0,001 \mathrm{~m}^{3}$ atau $1 \mathrm{dm}^{3}$ identik dengan 1 liter.

\section{Nilai Rerata Curah Hujan Bulanan}

Dari data tersebut hitung nilai rata-rata curah hujan selama 10 tahun, dengan mengunakan persamaan sebagai berikut:

$\bar{X}=\frac{\sum X i}{\text { Junlah } \operatorname{tahun}(n)}$

dimana:

$\overline{X \imath} \quad=$ Rerata curah hujan maksimum (mm)

$\sum X i=$ Jumlah curah hujan tiap tahun

$n \quad=$ jumlah tahun (data)

Tabel 6. Rerata curah hujan bulanan ( $\mathrm{mm} / \mathrm{bulan}$ ) di SC

\begin{tabular}{|c|c|c|c|c|c|c|c|c|c|c|c|c|c|c|}
\hline \multirow{2}{*}{$\begin{array}{l}\text { Ta- } \\
\text { hun }\end{array}$} & \multicolumn{12}{|c|}{ Bulan } & \multirow{2}{*}{ Total } & \multirow{2}{*}{ Rerata } \\
\hline & Jan & Feb & Mar & Apr & Mei & Juni & Juli & Agu & Sep & Okt & Nov & Des & & \\
\hline 2009 & 607 & 541 & 408 & 228 & 389 & 128 & 87 & 15 & 76 & 392 & 331 & 236 & 3,438 & 287 \\
\hline 2010 & 417 & 526 & 485 & 84 & 291 & 257 & 139 & 306 & 375 & 445 & 287 & 300 & 3,911 & 326 \\
\hline 2011 & 390 & 265 & 226 & 219 & 175 & 140 & 36 & 8 & 58 & 296 & 412 & 268 & 2,492 & 208 \\
\hline 2012 & 384 & 348 & 240 & 321 & 152 & 64 & 41 & 12 & 122 & 260 & 366 & 423 & 2,733 & 228 \\
\hline 2013 & 851 & 346 & 409 & 349 & 494 & 135 & 279 & 135 & 71 & 355 & 323 & 591 & 4,336 & 361 \\
\hline 2014 & 1,138 & 624 & 290 & 407 & 244 & 199 & 344 & 250 & 34 & 94 & 549 & 459 & 4,631 & 386 \\
\hline 2015 & 285 & 345 & 341 & 207 & 148 & 17 & 9 & 344 & 19 & 52 & 523 & 414 & 2,703 & 225 \\
\hline 2016 & 310 & 587 & 574 & 467 & 291 & 213 & 266 & 101 & 431 & 398 & 329 & 181 & 4,148 & 346 \\
\hline
\end{tabular}




\begin{tabular}{|c|c|c|c|c|c|c|c|c|c|c|c|c|c|c|}
\hline \multirow{2}{*}{$\begin{array}{l}\text { Ta- } \\
\text { hun }\end{array}$} & \multicolumn{12}{|c|}{ Bulan } & \multirow{2}{*}{ Total } & \multirow{2}{*}{ Rerata } \\
\hline & Jan & Feb & Mar & Apr & Mei & Juni & Juli & Agu & Sep & Okt & Nov & Des & & \\
\hline 2017 & 273 & 689 & 311 & 401 & 239 & 133 & 357 & 49 & 33.7 & 375 & 446 & 362 & 3,668 & 306 \\
\hline 2018 & 340 & 798 & 444 & 291 & 150 & 152 & 9 & 21 & 162 & 135 & 412 & 232 & 3,145 & 262 \\
\hline Total & 4,994 & 5,067 & 3,727 & 2,973 & 2,573 & 1,438 & 1,566 & 1,241 & 1,381 & 2,803 & 3,978 & 3,466 & 35,207 & - \\
\hline Rerata & 499 & 507 & 373 & 297 & 257 & 144 & 157 & 124 & 138 & 280 & 398 & 347 & 3520.7 & 293 \\
\hline
\end{tabular}

Sumber: BMKG Citeko, 2009 - 2018.

Rerata curah hujan selama 10 tahun $(\bar{X})=2.934 / 10=293$. Rerata curah hujan bulanan ( $\mathrm{mm} /$ bulan) dan standar deviasi disajikan pada Tabel 7.

\section{Standar Deviasi}

Kemudian hitung standar deviasi menggunakan persamaan sebagai berikut:

$S x=\sqrt{\sum \frac{(x i-\bar{x})^{2}}{n-1}}$

dimana:

$S x=$ Standar deviasi

$x i=$ jumlah curah hujan tiap tahun (tahun ke $-\mathrm{i}$ )

$\bar{x}=$ jumlah rerata curah hujan maksimum (mm)

$S_{x}=61,87$

\section{Curah Hujan Harian}

Selanjutnya hitung curah hujan harian maksimum 24 jam $(\mathrm{mm} / 24$ jam) dengan menggunakan persamaan distribusi probabilitas Gumbel sebagai berikut:

$R_{24}=\bar{X}+\frac{s_{x}}{s_{y}}\left(y_{t}-y_{n}\right)$

dimana:

$R_{24}=$ Besarnya curah hujan harian maksimum 24 jam (mm/24jam)

$\bar{X}=$ Rerata curah hujan (mm)

$S_{x}=$ Standar deviasi

$y_{n}=$ Rataan reduksi (Tabel)

$y_{t}=$ Variasi reduksi sebagai periode ulang (Tabel)

$S_{n}=$ Standar deviasi reduksi (Tabel)

Tabel 7. Rerata curah hujan bulanan ( $\mathrm{mm} / \mathrm{bulan}$ ) dan standar deviasi

\begin{tabular}{cccc}
\hline Tahun & Curah Hujan, Xi $(\mathrm{mm})$ & $(\mathrm{Xi}-\bar{X})$ & $(\mathrm{Xi}-\bar{X})^{\wedge} 2$ \\
\hline 2009 & 286.53 & -7 & 47.13 \\
2010 & 325.95 & 33 & $1,060.15$ \\
2011 & 207.69 & -86 & $7,344.20$ \\
2012 & 227.73 & -66 & $4,311.89$ \\
2013 & 361.37 & 68 & $4,620.83$ \\
2014 & 385.93 & 93 & $8,562.73$ \\
2015 & 225.28 & -68 & $4,638.52$ \\
2016 & 345.65 & 52 & $2,731.11$
\end{tabular}




\begin{tabular}{|c|c|c|c|}
\hline Tahun & Curah Hujan, Xi (mm) & $(\mathrm{Xi}-\bar{X})$ & $(\mathrm{Xi}-\bar{X})^{\wedge} 2$ \\
\hline 2017 & 305.70 & 12 & 151.54 \\
\hline 2018 & 262.08 & -31 & 980.11 \\
\hline Jumlah & $2,933.90$ & - & $34.448,20$ \\
\hline Rerata & 293.39 & - & - \\
\hline Standar deviasi & 61,87 & - & - \\
\hline
\end{tabular}

Sumber: Hasil analisis, 2019

Dengan jumlah data $(n)=10$, didapat nilai Sn dan Yn yang diambil dari tabel Gumbel seperti disajikan pada Tabel 8.

\section{Tabel 8. Nilai Sn dan Yn Gumbel}

\begin{tabular}{cc}
\hline $\mathrm{S}_{\mathrm{n}}$ & 0,9497 \\
\hline \hline $\mathrm{Y}_{\mathrm{n}}$ & 0,4952 \\
\hline
\end{tabular}

Nilai Yt berdasarkan sesuai dengan periode ulang disajikan pada Tabel 9 seperti di bawah ini.

Tabel 9. Nilai Yt Gumbel

\begin{tabular}{ll}
\hline Periode Ulang T (tahun) & $\mathrm{Y}_{\mathrm{t}}$ \\
\hline 2 & 0,3065 \\
5 & 1,4999 \\
20 & 2,9702 \\
50 & 3,9019 \\
100 & 4,6001 \\
\hline
\end{tabular}

$R_{24}=\bar{X}+\overline{S_{x}}\left(y_{t}-y_{n}\right)=293+\frac{61,87}{0.9497}(1.4999-0,4952)$

$R_{24}=358,45$

\section{Intensitas Hujan}

Intensitas curah hujan rata-rata periode 10 tahun $(\mathrm{mm} / \mathrm{jam})$ dihitung menggunakan persamaan Mononobe (Sosrodarsono \& Kensaku, 1983) dengan persamaan sebagai berikut: $I=\frac{R_{24}}{24}\left(\frac{24}{t}\right)^{2 / 3}$ dimana:

$I \quad=$ Intensiitas curah hujan ( $\mathrm{mm} / \mathrm{jam})$

$R_{24}=$ Curah hujan maksimum harian selama 24 jam (mm)

$t \quad=$ Lamanya hujan (24 jam)

$I=\frac{R_{24}}{24}\left(\frac{24}{t}\right)^{2 / 3}$

$I=\frac{358,45}{24}\left(\frac{24}{24}\right)^{2 / 3}$

$I=14,93 \mathrm{~mm} / \mathrm{jam}$

\section{Limpasan puncak}

Limpasan puncak di kawasan SC (Qp_SC) dapat dihitung dengan persamaan (Seyhan, 1990) sebagai berikut:

Qp_SC $=0,278 \times C_{S C} \times \mathrm{I} \times \mathrm{A}$

dimana:

Qp_SC = Limpasan puncak di kawasan SC ( $\mathrm{m}^{3} /$ detik)

$C_{S C} \quad=$ Koefisen limpasan untuk berbagai penggunaan lahan di kawasan SC 
I $\quad=$ Intensitas hujan $(\mathrm{mm} / \mathrm{jam})$

A $\quad=$ Luas wilayah kajian $\left(\mathrm{km}^{2}\right)$

Konstanta 0,278 adalah faktor konversi limpasan puncak ke satuan dalam $\mathrm{m}^{3} /$ detik (Seyhan, 1990). Luas eksisting SC sebesar $29,05 \mathrm{~km}^{2}$, dengan koefisien limpasan puncak $\left(C_{S C}\right)$ sebesar 0,40 dengan nilai limpasan puncak (Qp_SC) sebesar 48,29 $\mathrm{m}^{3} /$ detik. Perhitungan sebagaimana di bawah ini:

Qp_SC $=0,278 \times C \times I \times A=0,278 \times 0,40 \times 14,93 \times 29,05=48,29 \mathrm{~m}^{3} / \mathrm{detik}=$ $1,522,873,440 \mathrm{~m}^{3} /$ tahun

Koefisien limpasan puncak berdasarkan Masterplan (2011) sebesar 0,61 dengan nilai limpasan puncak (Qp_SC) sebesar 73,55 m³/detik. Perhitungan sebagaimana di bawah ini (Metode Rasional) dengan persamaan:

Qp_SC $=0,278 \times C \times I \times A=0,278 \times 0,61 \times 14,93 \times 29,05=73,55 \mathrm{~m}^{3} /$ detik $=$ 2.319.472.800 $\mathrm{m}^{3} /$ tahun.

Apabila curah hujan ke wilayah kajian semuanya menjadi limpasan $\left(C_{S C}=1\right)$ maka puncak limpasan (Qp_SC) sebesar 120,73 $\mathrm{m}^{3} /$ detik.

Qp_SC $=0,278 \times C \times I \times A=0,278 \times 1,00 \times 14,93 \times 29,05=120,73 \mathrm{~m}^{3} /$ detik $=$ 3.807.341.280 $\mathrm{m}^{3} /$ tahun.

Prediksi limpasan puncak rencana induk pengembangan (Master plan, 2011) dan LU/LC eksisting (tahun 2017) masing-masing sebesar 0,61 dan 0,40 terjadi kenaikan 0,21. Dengan kenaikan limpasan puncak ini akan menaikan debit air maksimum pada sungai yang berada di kawasan SC yaitu sungai Citeureup dan sungai Cikeas yang bermuara di wilayah Bekasi, sehingga akan berkonstribusi terhadap banjir yang berada daerah hilir yaitu Kota/Kabupaten Bekasi.

Pada studi kaitan antara perubahan wilayah perkotaan dengan karakteristik limpasan permukaan di distrik/kabupaten Mueang Maha Sarakham dan Kantharawichai Provinsi Maha Sarakham-India, memiliki hubungan dan efek yang kuat. Demikian juga, tingkat urbanisasi sangat terkait dengan rerata limpasan dalam zonasi. Hasil penelitian menunjukkan bahwa perubahan LU/LC memiliki efek pada karakteristik limpasan (Ongsomwang \& Pimjai, 2015). Urbanisasi d DAS Sungai Ala-Nigeria, yang memodifikasi LU dan tutupan lahan menjadi tutupan kedap air sehingga menghasilkan limpasan yang lebih tinggi di aliran DAS. Pada tahun 2042, area yang dibangun diproyeksikan meningkat menjadi $74,7 \%$ dari luas daerah aliran sungai $46,5 \%$ di tahun 2017. Kurva dan awal abstraksi yang diadopsi untuk klasifikasi tata guna lahan dan tutupan lahan di DAS adalah 86 dan 8.27. Volume puncak dan volume limpasan di outlet jangkauan, diperkirakan dengan periode 25 tahun untuk LU/LC pada tahun 2042 adalah 169,0 m3 / dtk dan 2.992 .500 m3. Volume limpasan puncak di outlet jangkauan, diperkirakan dengan periode ulang 25 tahun untuk LU dan tutupan lahan pada tahun 2042 adalah 254,3 m³ / dtk dan 3.698.000 m3 (Obiora-Okeke, 2019). Di DAS Musi-India yang meliputi sebagian besar wilayah perkotaan, peningkatan area terbangun mempengaruhi peningkatan limpasan dan C untuk tahun 2010, 2011 dan 2013 masing-masing sebesar 0,55, 0,59, dan 0,68 (Srinivas \& Naik, 2017). Karena urbanisasi di wilayah Beijing Cina, dari tahun 1992 hingga 2009, model limpasan meningkat 30\% untuk seluruh area dan 35\% untuk perkotaan (Sun et al, 2014). Menurut Manaschintan \& Nalini (2019), bahwa peningkatan eksponensial dalam urbanisasi menghasilkan peningkatan simulasi limpasan di Mumbai-India selama dua dekade (dari 1995 hingga 2016). Meningkatnya aliran permukaan, naiknya urbanisasi serta penebangan hutan secara sembarangan merupakan faktor terpenting yang berkontribusi terhadap meningkatnya limpasan di wilayah DAS di utara Iran, dan pengembangan daerah pemukiman baru menyebabkan peningkatan paling signifikan pada limpasan (Zare et al, 2016). Perubahan terhadap elemen meteorologi dan sifat fisik daerah akan berdampak terhadap naik turunnya limpasan dan debit, sebagaimana hasil riset di daerah aliran sungai (DAS) Merangin Tembesi 
Jambi, bahwa perubahan LU menyebabkan penurunan $40 \%$ dari debit minimum di musim kemarau dan $65 \%$ peningkatan debit puncak maksimum di musim hujan (Tarigan \& Faqih, 2019). Perubahan LU dari hutan ke non hutan dalam skala besar menyebabkan kerusakan lingkungan dan mengurangi fungsi hidrologis DAS Ciliwung-Bogor (Nuraidaa, Rachman, \& Baskoro, 2016). Pada studi pemodelan estimasi kehilangan tutupan hutan di Afrika Timur terhadap debit tahunan dan limpasan, terjadi peningkatan masing-masing sebesar $16 \pm 5,5 \%$ dan $45 \pm 14 \%$. Debit puncak meningkat rata-rata $10 \pm 2,8 \%$, sementara debit minimum menurun rata-rata $7 \pm 5,3 \%$. Peningkatan tutupan hutan mengurangi debit tahunan dan limpasan permukaan masing-masing sebesar $13 \pm 1,9 \%$ dan $25 \pm 5 \%$ (Guzhaa et al, 2018).

Perubahan tutupan lahan di DAS Duhok-Iraq dengan pertumbuhan kota (urban growth) pada tahun 1990 dan 2016 meningkat dari 10\% menjadi 70\%, berdampak terhadap volume limpasan meningkat dari $12 \%$ menjadi $36 \%$, sementara lahan vegetasi menurun dari 47\% menjadi 14\% pada saat yang sama (Hameed., Faqe., \& Rasul, 2020). Perubahan LU/LC menunjukkan hubungan linier dengan besarnya limpasan, dan faktor paling signifikan yang mempengaruhi limpasan adalah perbedaan LU hutan, pertanian, dan pemukiman (Astuti et al, 2019). Berdasarkan hasil penelitian pada dua Daerah Aliran Sungai (DAS) di Kerala-India bahwa LU/LC memengaruhi karakteristik limpasan, yang pada gilirannya mempengaruhi ketersediaan air permukaan dan air tanah di wilayah tersebut, dan karenanya menyebabkan perubahan lebih lanjut pada LU/LC. Ini membentuk siklus. Oleh karena itu menjadi penting untuk menilai dampak perubahan LU/LC pada karakteristik limpasan suatu wilayah secara umum dan tingkat DAS kecil (tingkat sub-DAS) pada khususnya. Analisis ini dapat secara efektif dilakukan dengan menggunakan model simulasi DAS dengan kerangka kerja Sistem Informasi Geospasial terintegrasi (Sajikumar \& Remya, 2015).

Berdasarkan hasil penelitian di Sungai Nyando, DAS Lake Victoria-Kenya, Efek perubahan LU menunjukkan terjadi peningkatan nilai debit puncak yang signifikan, terutama di daerah hulu akibat tingkat penebangan hutan (deforestasi) yang tinggi. Debit puncak meningkat sebesar $16 \%$ di semua 14 sub-DAS. Simulasi volume banjir di DAS juga meningkat 10\% dibandingkan periode yang sama (Kundu \& Olang, 2011).

Hasil penelitian di DAS Jinjiang-Cina, bahwa limpasan tahunan memiliki peningkatan terkecil di antara dua skenario (tahun 1985 dan 2006), limpasan bulanan memiliki laju sedang (meningkat pada semua bulan kecuali Oktober-November), dan limpasan harian memiliki laju terbesar dengan peningkatan puncak banjir, tetapi penurunan debit minimum, karena pengaruh yang bervariasi pada kehilangan intersepsi/ evapotranspirasi, perkolasi dan umur penyimpanan air tanah sebelumnya. Indikator skala waktu yang berbeda (limpasan tahunan, limpasan bulanan, limpasan maksimum banjir 1 hari dan 5 hari, limpasan minimum 1 hari dan 7 hari) dapat digunakan untuk menganalisis dampak perubahan LU dengan baik (Lin et al, 2015).

Besarnya limpasan akan berubah karena perubahan iklim dan perubahan LU sebagaimana hasil penelitian di wilayah Mediterania. Kedua aspek ini merupakan komponen yang sangat berpengaruh, sehingga perlu mengembangkan suatu kebijakan dalam pengelolaan sumber daya air wilayah/regional (Viola et al, 2019). Berdasarkan hipotesis Budyko (1974) pada pengukuran di stasiun Linjiacun dan Huaxian Cina, bahwa perubahan iklim dan LU berkontribusi terhadap perubahan limpasan pada masing-masing stasiun yaitu sebesar 42,2 \%, 57,8 \% dan 30,5 \%, 69,8 \% (Huang et al, 2016).

Hasil penelitian di DAS Tungabhadra River, penggundulan hutan, penambangan, praktik pertanian dan pertumbuhan ekonomi adalah beberapa faktor yang terkait dengan perubahan LU yang mengubah aliran arus sungai (Venkatesh \& Ramesh, 2018).

Berdasarkan hasil penelitian di DAS coastal-Texas Tenggara, menunjukkan bahwa jenis dampak spesifik LU/LC dikaitkan dengan kehilangan akibat banjir, memberikan 
panduan tentang bagaimana lingkungan dapat dikembangkan suapaya lebih tangguh dalam jangka panjang (Brody et al, 2014).

Secara nasional di wilayah Cina, rerata tahunan kedalaman limpasan pada tahun 2005, 2010 dan 2015 adalah $78 \mathrm{~mm}, 83 \mathrm{~mm}$, dan $90 \mathrm{~mm}$. Untuk data penggunaan lahan 2015, karena perubahan curah hujan menyebabkan variasi kedalaman limpasan mulai dari -203 $\mathrm{mm}$ hingga $476 \mathrm{~mm}$ di berbagai wilayah (Li et al, 2019). Empat komponen utama yang menentukan perubahan keseimbangan air tangkapan di DAS Mbarali-Tanzania adalah curah hujan, pengisian air tanah, penguapan, dan limpasan yang cenderung meningkat (Mutayoba et al, 2018).

Perubahan LU mengakibatkan perubahan terhadap besarnya nilai limpasan puncak. Limpasan puncak akan meningkat dengan menurunnya ruang terbuka hijau dan atau meningkatnya lahan terbuka (tidak bervegetasi). Upaya untuk menurunkan limpasan di SC dapat dilakukan diantaranya dengan penanaman vegetasi (menambah ruang terbuka hijau) untuk meningkatkan resapan air ke dalam tanah. Dismping hal tersebut, ketersediaan ruang terbuka hijau yang rendah juga dapat menurunkan daya dukung lingkungan biotik dalam mengatasi efek dari aktivitas manusia (antropogenik) di kawasan perkotaan (Sari et al, 2019) seperti halnya di SC. Upaya lain untuk menurunkan limpasan dapat dilakukan dengan menampung air dengan pembangunan danau buatan, sumur resapan, lubang biopori resapan, panen air langsung (rainwater harvesting) dengan tank pintar penampung air (smart tank), dan pemanfaatan air sungai.

\section{KESIMPULAN}

Berdasarkan hasil klasifikasi pada citra SPOT-6 tahun 2017 diperoleh 12 jenis LU/LC eksisting, sebagian besar lahan berupa tegalan sebesar $41.77 \%$, pemukiman perkotaan $24.48 \%$, kebun campuran $10.23 \%$, perairan darat $0.22 \%$ dan lahan terbuka $0.33 \%$. C puncak berdasarkan LU/LC eksisting sebesar 0,40 atau limpasan puncak 48,29 $\mathrm{m}^{3} /$ detik atau 1.522.873.440 $\mathrm{m}^{3} /$ tahun, dan berdasarkan Master plan sebesar 0,61 dengan limpasan puncak (Qp_SC) sebesar 73,55 $\mathrm{m}^{3} /$ detik atau 2.319.472.800 $\mathrm{m}^{3} /$ tahun. Terjadi perubahan nilai $C$ puncak akibat perubahan LU eksisting terhadap rencana induk pengembangan (Master plan, 2011) sebesar 0,21 atau limpasan puncak 25,32 m3/detik atau 6.622.560 $\mathrm{m} 3 /$ tahun.

Perubahan LU/LC mengakibatkan perubahan terhadap besarnya nilai limpasan puncak. Limpasan puncak akan meningkat dengan menurunnya ruang terbuka hijau dan atau meningkatnya lahan terbuka (tidak bervegetasi). Kenaikan limpasan puncak akan menaikan debit air maksimum sungai yang berada di kawasan SC (yaitu sungai Citeureup dan sungai Cikeas) yang bermuara di wilayah Bekasi, sehingga akan berkonstribusi terhadap banjir Kota/Kabupaten Bekasi. Upaya untuk menurunkan limpasan dapat dilakukan dengan menampung air dengan pembangunan danau buatan, sumur resapan, lubang biopori resapan, panen air hujan (rainwater harvesting) dengan tank pintar penampung air (smart tank), dan pemanfaatan air sungai.

\section{DAFTAR PUSTAKA}

Aronoff, S. 1989. Geographic Information Systems. A Management Perspective, WDL Publication, Otawa, Canada.

Arsyad, S. 2010. Konservasi Tanah dan Air. Bogor (ID): IPB Press.

Asdak, C. 2010. Hidrologi dan Pengelolaan DAS. Gadjah Mada University Press, Yogyakarta.

Astuti, I.S., Sahoo, K., Milewski, A., \& Mishra, D.R. 2019. Impact of Land Use Land Cover (LU/LC) Change on Surface Runoff in an Increasingly Urbanized Tropical Watershed. Water Resources Management volume 33, pages 4087-4103(2019).

[BAPPEDA] Badan Perencanaan dan Pembangunan Daerah Pemerintah Kabupaten Bogor (ID). Rencana Tata Ruang Wilayah Kabupaten Bogor 2005-2025. Bogor (ID): Bappeda Kabupaten Bogor. 
Barret, E., Curtis, L.F. 1982. Introduction to Enviromental Remote Sensing (2nd Edition ed.). London: Chapman and Hall.

Barus, B., Wiradisastra, U.S. 2000. Sistem Informasi Geografi, Laboratorium Penginderaan Jauh dan Kartografi, Jurusan Tanah, Fakultas Pertanian IPB, Bogor.

Brody, S., Blessing, R., Sebastian, A., \& Bedient, P. 2014. Examining the impact of land use/land cover characteristics on flood losses. Journal of Environmental Planning and Management Volume 57, 2014 Issue 8 https://doi.org/10.1080/09640568.2013.802228.

Budyko, M. I.: 1974, Climate and Life, Academic Press, New York, 508 pp.

Burrough, P.A. 1987. Principle of Geographical Information System for Land Resources Assessment. Oxford : Clarendon Press.

Dulbahri. 1993. Sistem Informasi Geografis, PUSPIC, Universitas Gadjah Mada, Yogyakarta.

Goldman, S.J., Jackson, K., Bursztynsky, T.A. 1986. Erosion and Sediment Control Handbook. McGraw Hill Book Co., New York.

Gumbel, E.J. 1954. Statistical theory of extreme values and some practical applications. Applied Mathematics Series. 33 (1st ed.). U.S. Department of Commerce, National Bureau of Standards.

Guzhaa, A.C., Rufino, M.C., Okoth, S., Jacobs, S., Nóbrega, R.L.B. 2018. Impacts of land use and land cover change on surface runoff, discharge and low flows: Evidence from East Africa. Journal of Hydrology: Regional Studies Volume 15, February 2018, Pages 49-67. https://doi.org/10.1016/j.ejrh.2017.11.005.

Gunawan, T., Sudaryatno., Gisarsih, S. 2012. Pedoman Karakteristik DAS. Laporan Penelitian Kerjasama. Kementrian Kehutanan Republik Indonesia.

Hameed H.M., Faqe G.R., Rasul A. (2020) Effects of Land Cover Change on Surface Runoff Using GIS and Remote Sensing: A Case Study Duhok Sub-basin. In: Al-Quraishi A., Negm A. (eds) Environmental Remote Sensing and GIS in Iraq.pp205-223. Springer Water. Springer, Cham. https://doi.org/10.1007/978-3-030-213442_ 9

Haridjaja, O., Murtilaksono, K., Sudarmo., dan Rachman, LM. 1991. Hidrologi Pertanian. Jurusan Tanah. Fakultas Pertanian. Institut Pertanian Bogor. Bogor.

Huang, S., Chang, J., Huang, Q., Chen, Y., \& Leng, G. 2016. Quantifying the Relative Contribution of Climate and Human Impacts on Runoff Change Based on the Budyko Hypothesis and SVM Model. Water Resources Management volume 30, pages2377-2390(2016).

Kasiro. 1994. Pedoman Kriteria Desain Embung Kecil Untuk Daerah Semi Kering Di Indonesia. Pusat LITBANG Pengairan Badan LITBANG Pekerjaan Umum Departemen Pekerjaan Umum. Bandung.

Kodoatie, R.J., dan Sjarief, R. 2008. Pengelolaan Sumber Daya Air Terpadu. Yogyakarta: Andi.

Kundu, P.M., \& Olang, L.O. 2011. The impact of land use change on runoff and peak flood discharges for the Nyando River in Lake Victoria drainage basin, Kenya. WIT Transactions on Ecology and The Environment, Vol 153,@ 2011 WIT Press. doi:10.2495/WS110081.

Li, F., Chen, J., Jingqiu., Yaoze, C., Yaoze, L., Show, L., Wang, S. 2019. Assessment of the Impacts of Land Use/Cover Change and Rainfall Change on Surface Runoff in China. Sustainability 11(13):3535(1-19). https://DOI:10.3390/su11133535.

Lillesand, M.T., Kiefer, R.W. 1994. Remote Sensing and Image Interpretation (Third Editioned.). New York: John Wiley \& Son, Inc.

Lin, B., Chen, X., Yao, H., Chen, Y., Liu, M., Gao, L., James, A. 2015. Analyses of landuse change impacts on catchment runoff usingdifferent time indicators based on SWAT model. Ecological Indicators 58 (2015) 55-63. http://dx.doi.org/10.1016/j.ecolind.2015.05.031.

Manaschintan, S.B., and Nalini, S.S. 2019. Effect of Land Use-Land Cover Change on Runoff Characteristics in Mumbai City, India. Applications of Geomatics in Civil Engineering pp 183-192.

Mujere, N. 2011. Flood frequency analysis using the Gumbel distribution. International Journal on Computer Science and Engineering (IJCSE), vol. 3, pp. 2774-2778, July 2011.

Mutayoba, E., Kashaigili, J., Kahimba, F.C., Chilagane, N.A. 2018. Assessing the Impacts of Land Use and Land Cover Changes on Hydrology of the Mbarali River Sub-Catchment. The Case of Upper Great Ruaha Sub-Basin, Tanzania. Engineering 10(09):616-635. DOI: 10.4236/eng.2018.109045.

Needhidasan, S., Manoj, N. 2013. Design of storm water drains by rational method -anapproach to storm water management for environmental protection. IJET. 5(4): 3203-3214. ISSN : 0975-4024. 
Nuraidaa., Rachman, LM., Baskoro, D.P.T. 2016. Analisis nilai konservasi tinggi aspek pengendali erosi dan sedimentasi (HCV 4.2) di DAS Ciliwung Hulu. Jurnal Pengelolaan Sumberdaya Alam dan Lingkungan Vol. 6 No. 2 (Desember 2016): 151-159.

Nurshanti. 1995. Konsep-konsep Dasar sistem Informasi Geografis.Informatika. Bandung.

Obiora-Okeke, O.A. 2019. Changing land use and land cover impact on runoff characteristics of an upstream reach in Ala river watershed. American Journal of Engineering Research (AJER), vol.8, no.06, 2019, pp.8086.

Ongsomwang, S., and Pimjai, M. 2015. Land Use and Land Cover Change and Its Impact on Surface Runoff. Suranaree J. Sci. Technol. Vol. 22 No. 2; April - June 2015.

Pemerintah Republik Indonesia. 2011. Undang-Undang Republik Indonesia No. 4 Tahun 2011 tentang Informasi Geospasial. Jakarta (ID): Sekretariat Negara.

Pemerintah Republik Indonesia. 2007. Undang-Undang Republik Indonesia No. 26 Tahun 2007 tentang Penataan Ruang. Jakarta (ID): Sekretariat Negara.

Pemerintah Kabupaten Bogor. 2008. Peraturan Daerah Kabupaten Bogor No. 19 Tahun 2008 tentang Rencana Tata Ruang Wilayah Kabupaten Bogor Tahun 2005 - 2025. Bogor: Sekretariat Daerah Kabupaten Bogor.

Ponce, V.M. 1989. Engineering Hydrology : Principles and Practices. Prentice-Hall, New Jersey.

Sajikumar, N., and Remya, R.S. 2015. Impact of land cover and land use change on runoff characteristics. Journal of Environmental Management 161 (2015) 460-468. http://dx.doi.org/10.1016/j.jenvman.2014.12.041.

Sari, C.P., Wiryanto., Setyono, P. 2019. Aplikasi penginderaan jauh untuk mengkaji tutupan vegetasi kawasan urban kota Surakarta 2017 menggunakan citra satelit sentinel 2A. Jurnal Pengelolaan Sumberdaya Alam dan Lingkungan Vol. 9 No. 1 (Maret 2019): 152-158.

Sentul City (ID). 2011. Masterplan 2465 Ha SC (Revisi). Bogor (ID): PT SC Tbk.

Seyhan, E. 1990. Dasar-dasar Hidrologi (terjemahan Fundamental of Hydrology oleh sentot subagya),Gadjah Mada University Press, Yogyakarta.

Sosrodarsono, S., Kensaku, T. 2003. Hidrologi Untuk Pengairan, Pradnya Paramita, Jakarta.

Srinivas, G., \& Naik, G.M. 2017. Hydrological Modeling of Musi River Basin and Impact Assessment of Land Use Change on Urban Runoff. International Journal of Engineering Research \& Technology (IJERT) Vol. 6 Issue 07, July - 2017.

Sun, Z., Xinwu Li, X., Fu, W., Yingkui Li, Y., and Tang, D. Long-term effects of land use/land cover change on surface runoff in urban areas of Beijing, China. Journal of Applied Remote Sensing, Vol. 8, 084596-(1-18), 2014.

Tarigan, S., Faqih, A. 2019. Impact of changes in climate and land use on the future streamflow fluctuation: case study Merangin Tembesi Watershed, Jambi, Indonesia. Jurnal Pengelolaan Sumberdaya Alam dan Lingkungan Vol. 9 No. 1 (Maret 2019): 181-189.

Theodore, G., Cleveland. 2011. Texas metropolitan ara: USGS Scientific Investigation Reports.

Townshend, J.R.G., Justice, C.O. 1981. Image Processing of Remotely Sensed Data -a user view. International Journal of Remote Sensing, 2, 313-330.

Venkatesh, K., \& Ramesh, H. 2018. Impact of Land Use Land Cover Change on Runoff Generation in Tungabhadra River Basin. ISPRS Annals of the Photogrammetry, Remote Sensing and Spatial Information Sciences, Volume IV-5, 2018. ISPRS TC V Mid-term Symposium "Geospatial Technology - Pixel to People”, 20-23 November 2018, Dehradun, India. https://doi.org/10.5194/isprs-annals-IV-5-367-2018.

Viola, F., Feng, X., \& Caracciolo, D. 2019. Impacts of Hydrological Changes on Annual Runoff Distribution in Seasonally Dry Basins. Water Resources Management volume 33, pages 2319-2333(2019).

Zare, M., Samani, A.A.N., \& Mohammady, M. 2016. The impact of land use change on runoff generation in an urbanizing watershed in the north of Iran. Environ Earth Sci(2016) 75:1279. https://DOI:10.1007s12665$\underline{016-6058-7 .}$ 